Historic, Archive Document

Do not assume content reflects current scientific knowledge, policies, or practices. 



\section{DESCRIPTIVE PRICE LIST of IMPROVED EUROPEAN FILBERT VARIETIES}

VOLLERTSEN - ARMSTRONG CO. OFFICE, 375 GREGORY ST., ROCHESTER, N. Y. NURSERY OFFICE, ARMSTRONG FARM DENISE ROAD, CHARLOTTE, NEW, YORK

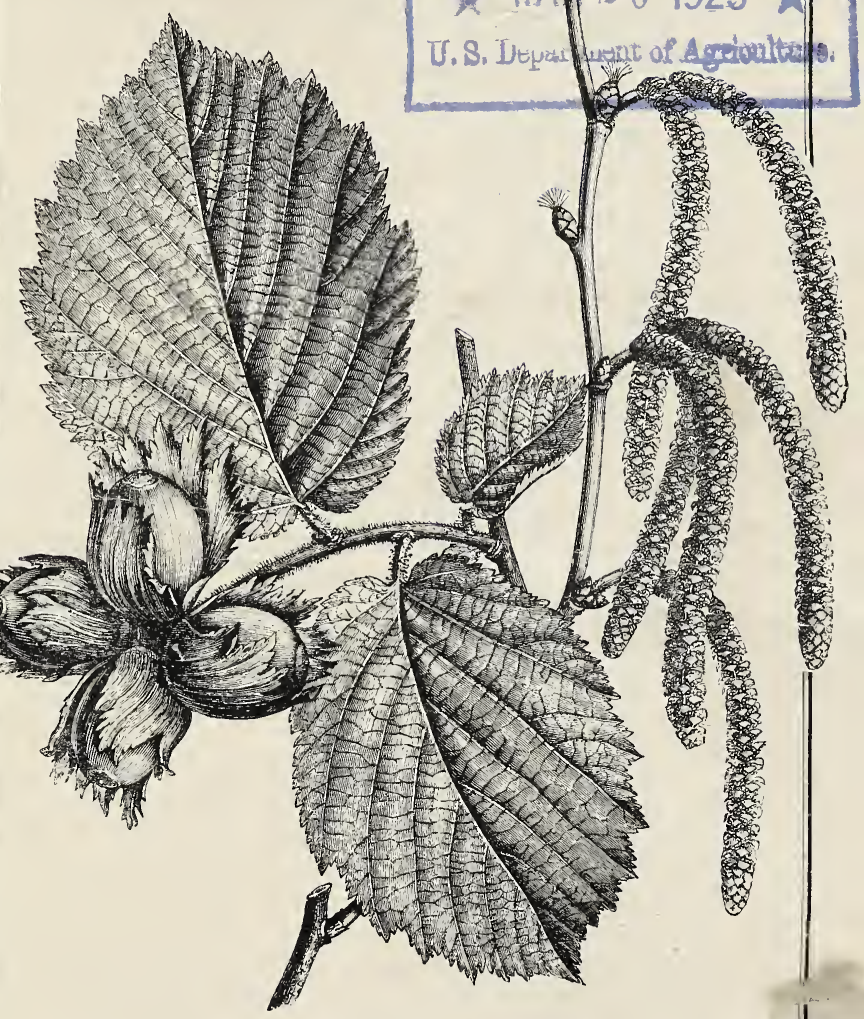

In presenting a descriptive price list of our selected Improved European Filbert varieties, the following statement seems to be in order: From our large collection of European filbert varieties, imported from Northern Europe a number of years ago, after practical experience and close observation in our nursery only the following varieties have been selected for future propagating and growing, as they have proven perfectly satisfactory in every particular. Hardiness, fruitfulness, size of nuts, etc. 
+ Althaldensleben. Tree low and drooping in growth, fruit small, very dark brown and handsome in appearance, of great value as a pollenizer for the larger varieties. Price $\$ 1.00$.

BARCELONA. Tree a very strong grower. Fruit very similar in size and shape to White Lambert but matures considerably later. Price $\$ 1.25$.

X BUTTNER'S ZELLER. Tree upright, thrifty and a good bearer, bushy somewhat spreading, very hardy. Nut medium, a good pollenizer. Price $\$ 1.00$.

e BONY BUSH. Tree upright. Thrifty. Nut very long. Slender, prolific. Very promising. Price $\$ 1.25$.

† BURKHARD'S ZELLER. Tree upright, bushy, somewhat spreading, a good bearer, excellent as a pollenizer. Resembles Buttner's. Price $\$ 1.00$.

DAVIANA. Tree upright, thrifty and a very good bearer. Nut quite large, very promising. Price $\$ 1.25$.

DU CHILLY. Tree upright, a very rank grower, very prolific. Nut large. We consider this a very promising variety. Price $\$ 1.25$.

EARLY GLOBE. Tree low and bushy, very hardy and a fine bearer. Fruit medium sized, very handsome, ripens very early. One of our best varieties. Price $\$ 1.00$.

\section{2}

IMPERIAL DE TREPISONDE. Tree upright and robust in growth. Vêry prolific. Nut very large, oblong, of good quality. Price $\$ 1.25$.

ITALIAN RED. One of the finest of the Improved Filberts. Nut large, of fine brown color, oblong, shell remarkably thin and kernel of excellent flavor. A fine upright grower and a prolific bearer. Price $\$ 1.25$.

KENTISH COB. Tree upright and conical in growth. Thrifty and prolific. Nut large, very long, somewhat light in color. One of our best varieties. Price \$1.25.

X LARGE GLOBE. Similar in every respect to Merveille De Bollwiller. We have had them both under observation for several years and we are of the opinion that they are the same variety but as we are not fully convinced of this we are treating them as separate varieties until we have given them more thorough observation. Price $\$ 1.25$. 


\section{VOL. ISEIV-ARMSTRONG CO. \\ Improved European Filberts}

Office, 375 Gregory Street, Rochester, N. Y.

\section{Nursery Office, Armstrong Farm}

Denise Road, Charlotte, N. Y.

We have for sale this season an exceptionally fine lot of Improved European Filbert Plants, 2-3 years old, of choicest named varieties suitable for Ornamental purposes, as well as for the nuts, combining Beauty with Profit. All plants have been duly inspected and found perfectly healthy and free from insects or fungus.

The growing of Improved European Filbert Nuts, a rather new enterprise in our Country, has proven quite successful. Since our plants became of bearing age, fine well matured crops have been harvested year after year, and as the plants are perfectly hardy and require comparatively little attention, a few of them should be planted in every garden and, for commercial purposes orchards should be established, as nuts will eventually become quite an item to our food supply.

Prices: From $\$ 1.00$ to $\$ 1.25$ per plant, f. o. b. Rochester, N. Y., according to size and variety.

Wholesale prices on request.

Terms: Cash with order or on delivery, except when otherwise arranged.

\section{Vollertsen-Armstrong Co.}



MEDIUM LONG. Tree upright and vigorous, somewhat bushy. Fruit long, narrow, medium to large, beautifully striped. IVe consider this a very fino nut. Price $\$ 1.25$.

MERVEILLE DE BOLLWILLER. Tree upright, conical, very vigorous and handsome. Fruit resembles Red Lambert. Short, broad, very showy. One of our largest nuts. Price $\$ 1.25$.

MINNA'S ZELLER. Tree low, drooping. Nut large, almost round, quite early. A very valuable variety and an excellent pollenizer. Price $\$ 1.00$.

+ NOCE LUNGHE. Tree a vigorous grower of spreading habit. Nut very large somewhat resembling Italian Red. Price $\$ 1.25$.

RED LAMBERT. Tree spreading, a strong grower. Nut short and broad, very large and showy. Season quite late. Price $\$ 1.25$.

WHITE LAMBERT. Tree of low and drooping growth. Nut short and broad, large and a fine variety. Price $\$ 1.25$.

\section{AMERICAN VARIETIES}

MERREYBROOK. An American variety of some promise. Nut very small size, rather thick shelled. Very prolific. Tree low, bushy and of slender growth. Valuable as an ornamental as it is one of the few hazels that show beautiful coloring in the fall. Price $\$ 1.00$.

RUSH HAZEL. An American variety of somewhat low and bushy growth. Nut medium sized, rather thick shelled, flavor good. Price $\$ 1.00$.

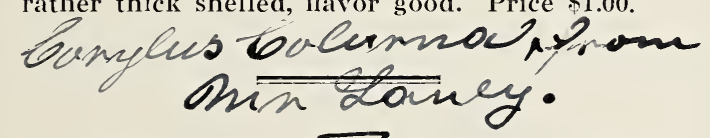

Other varieties, when recommended, old or new, will be thoroughly tested and if found worthy of cultivation, added to our collection.

All plants two to three feet, well branched.

All prices f. o. b. Rochester, N. Y.

Wholesale prices on request.

Terms cash with order except when otherwise arranged.

VOLLERTSEN-ARMSTRONG CO. 


\section{A Brief Direction of Treating the Improved European Filbert - Plants}

The soil all filberts prefer is sandy loam, but ordinary farm-land not too heary and not too wet is sufficient for them to grow and fruit well on. They require a free and open location, not shaded or overgrown by other trees.

The distance planted should be $12-15$ feet each way if planted in orchards or other large plantations; in hedges $4-5$ feet is sufficient.

Planting may be done in spring or fall witl equal success.

The ground should be kept well cultivated and free from weeds.

Manure or other fertilizers should be used rather sparingly.

The blossoms of all hazel or filbert plants are monoecious, but do not always open together, therefore one plant alone should never be planted; if there is not room for two or three plants and then of different varieties, my advice would be rather not to plant any, as it seldom proves satisfactory for want of pollination.

The pruning of filbert plants is a very important factor to their well doing. The center of all plants should be kept open at all times; if necessary some of the center limbs should be removed entirely, not only cut back; also if possible trim all plants to a single stem and keep clear of all branches to a height of about 12-15 inches.

All hazel and filbert plants with the exception of the tree hazel are inclined to grow a number of shoots from the roots, so-called suckers. They should be eradicated as soon as they make their appearance; this is very important.

All plants should be kept low from young up; 8-10 feet in height should be about the limit.

Remove limbs whenever the branches seem to become too close or too thick. Always trim with that point in view, that fruit-bearing plants will not come in contact with each other. Also remove unsightly branches from the plants where they are too near the ground, thereby trying to maintain a pretty shape of the plant and further its fruitfulness.

The want of pruning and the growth of suckers makes the filberts in all gardens and orchards completely barren 